\title{
Epigenetic modulation associated with carcinogenesis and prognosis of human gastric cancer (Review)
}

\author{
FUMINORI SONOHARA $^{1,2}$, YOSHIKUNI INOKAWA ${ }^{1,2}$, \\ MASAMICHI HAYASHI ${ }^{1}$, YASUHIRO KODERA ${ }^{1}$ and SHUJI NOMOTO ${ }^{1,2}$ \\ ${ }^{1}$ Department of Gastroenterological Surgery, Nagoya University Graduate School of Medicine, Nagoya, Aichi 466-8550; \\ ${ }^{2}$ Department of Surgery, Aichi-Gakuin University School of Dentistry, \\ Nagoya, Aichi 464-8651, Japan
}

Received October 9, 2015; Accepted February 14, 2017

DOI: $10.3892 / \mathrm{ol} .2017 .5912$

\begin{abstract}
Gastric cancer (GC) is a leading cause of cancer-related death, particularly in Asia.Epidemiological and other clinical studies have identified an association between a number of risk factors, including Helicobacter pylori, and GC. A number of studies have also examined genetic changes associated with the development and progression of GC. When considering the clinical significance of the expression of a specific gene, its epigenetic modulation should be considered. Epigenetic modulation appears to be a primary driver of changes in gastric tissue that promotes carcinogenesis and progression of GC and other neoplasms. The role of epigenetic modulation in GC carcinogenesis and progression has been widely studied in recent years. In the present review, recent results of epigenetic modulation associated with GC and their effects on clinical outcome are examined, with particular respect to DNA methylation, histone modulation and non-coding RNA. A number of studies indicate that epigenetic changes in the expression of specific genes critically affect their clinical significance and further study may reveal epigenetic changes as the basis for targeted molecular therapy or novel biomarkers that predict GC prognosis or extension of this often fatal disease.
\end{abstract}

\section{Contents}

1. Introduction

2. DNA methylation

3. Histone modulation

4. Non-coding RNA

Correspondence to: Dr Shuji Nomoto, Department of Surgery, Aichi-Gakuin University School of Dentistry, 2-11, Suemori-dori, Chikusa-ku, Nagoya, Aichi 464-8651, Japan

E-mail: snomoto@dpc.agu.ac.jp

Key words: epigenetic modulation, gastric cancer, DNA methylation, histone modulation, non-coding RNA

\section{Conclusions}

\section{Introduction}

Gastric cancer/carcinoma (GC) is a relatively common cancer, particularly in Asia (1). Although its incidence is decreasing gradually in developed countries, high morbidity and mortality of GC remains among cancer types $(2,3)$. Early GC may be treated, and even completely cured surgically, using endoscopic mucosal resection and endoscopic submucosal dissection $(4,5)$. However, the prognosis of advanced or distantly metastasized GC is worse. Although a number of systemic chemotherapy regimens are available to treat unresectable or distantly metastatic GC, highly advanced GC is difficult to completely cure using chemotherapy. Therefore, prevention or early detection of this fatal disease is critical. The epigenetic aspects of GC are an important current frontier in understanding its development and progression, and identifying its earliest stages.

Epidemiology and other clinical research have identified an association between several risk factors and GC. Helicobacter pylori is an influential factor in the carcinogenesis of GC (6). Certain dietary characteristics, including high sodium intake or low produce consumption are recognized risk factors for GC $(7,8)$. Many studies have also examined genetic changes related to GC development and progression. Whole human genome sequencing has been available since 2003, and has led to new insights into human diseases, including the genetic aspects of GC (9); both genetic and epigenetic changes have been demonstrated to orchestrate carcinogenesis and progression of neoplasms.

Notably, genetic and epigenetic changes have been identified to affect cancer development in a stepwise manner, although they may have limited effects separately. Epigenetic modulation, including DNA methylation status, histone modification and non-coding RNA modulation, greatly influences neoplastic development (10). Therefore, understanding how these epigenetic changes affect GC has importance in detecting, treating and preventing this fatal disease. In the present review, epigenetic modulation of GC in terms of its association with epidemiological factors and clinicopathological factors is outlined, and the clinical significance of 
epigenetic modulation in GC carcinogenesis and prognosis is summarized.

\section{DNA methylation}

Specific and genome-wide DNA methylation. Abnormal DNA methylation can be caused by internal and external factors, and is distributed in two general patterns, genome-wide hypomethylation and site-specific $\mathrm{CpG}$ island local hypermethylation $(11,12)$, which affect the prognosis of GC and other types of cancer. The methylation status of a gene's promoter region may determine whether or not it acts as a tumor suppressor; promoter regions of various tumor suppressor genes have been independently associated with prognosis of GC (13-20) (Table I).

The effect of whole-genome hypomethylation on GC was first described in 1996 (21). In that study, the authors identified that hypomethylation of DNA was increased in a stepwise manner in normal gastric mucosae, superficial gastritis and atrophic gastritis, but did not significantly increase between atrophic gastritis and GC. The European Prospective Investigation into Cancer and Nutrition cohort study identified that global demethylation of tumor cell genomes occurred in GC, which is consistent with the idea that abnormal hypermethylation of specific genes occurs concomitantly with genome-wide hypomethylation (22). Long interspersed element 1 (LINE-1), a retrotransposon, occupies $\sim 17 \%$ of human DNA; its hypomethylation is hypothesized to be a surrogate for whole-DNA hypomethylation. Bae et al (23) demonstrated that LINE-1 hypomethylation was an independent prognostic factor following curative resection for advanced GC. Shigaki et al (24) also identified an association between LINE-1 hypomethylation and shorter survival time in $\mathrm{GC}$, which suggests that it is a potent prognostic biomarker.

DNA methylation associated with etiological factors. A strong etiological factor in GC is H. pylori. Maekita et al (25) identified an association between $H$. pylori infection and hypermethylation of certain specific $\mathrm{CpG}$ islands. Furthermore, Chan et al (26) demonstrated that aberrant methylation of $\mathrm{CpG}$ islands in the epithelial cadherin promotor was an early event in $H$. pylori-induced GC carcinogenesis. Aberrant methylation has also been associated with Epstein-Barr virus, another virus associated with development of GC (27). Although associations between DNA methylation and habits including smoking or high sodium intake remain unclear, $\mathrm{Xu}$ et al (28) recently demonstrated that methylation of the gene encoding transmembrane protein 106A in primary GC was significantly associated with smoking and tumor metastasis. Furthermore, methylation of the genes encoding human MutL homolog 1 and human MutS homolog 3 were identified to be age-related and may therefore serve an important role in carcinogenesis of GC in the older population (29).

\section{Histone modulation}

Histone octamers package and order the DNA of eukaryotic cells into nucleosomes as part of the chromatin structure. Histones possess a tail-like structure that extends beyond the nucleosome and may be modulated; the majority of well-investigated histone modulations affect transcription. Histone modification assists with the regulation of pre-mRNA splicing (30). Ubiquitin-like containing PHD and RING finger domains 1-dependent histone $\mathrm{H} 3$ ubiquitination has been demonstrated to be critical in maintaining methylation during DNA duplication (31). Histone modulation, including methylation, acetylation, phosphorylation and ubiquitination, affect oncogene expression (32-36), although their clinical significance in patients with GC remains unclear. Cai et al (37) recently revealed that expression of histone-lysine N-methyltransferase $\mathrm{Suv} 39 \mathrm{H} 1$ and trimethylated histone $\mathrm{H} 3$ methylated lysine 9 ( $H 3 K 9$ ) was increased in GC, and trimethylated $H 3 K 9$ was identified to be positively associated with tumor stage and metastatic status (37).

\section{Non-coding RNA}

The Human Genome Project identified that although $\sim 80 \%$ of the human genome is transcribed into RNA, only $2 \%$ of those transcripts are translated into proteins. Numerous RNAs do not code for proteins in human cells, and are therefore called non-coding RNA. The functions of non-coding RNA have been partly elucidated, particularly for smaller transcripts. However, larger sized non-coding RNA is becoming more widely studied, particularly with regard to its roles in carcinogenesis and tumor progression.

MicroRNA (miRNA/miR). miRNA is a relatively short non-coding RNA of between 20 and 28 base pairs, and is derived from host DNA. miRNA has emerged as an important modulator of post-transcriptional regulation. miRNA regulates gene expression primarily by interfering with the transcription and cleavage of mRNA $(38,39)$. This interference may explain some discrepancies between mRNA production and corresponding protein expression. miRNA targets are thought to include $<30 \%$ of the human genome (40), and misregulation of miRNA expression affects development and progression of various diseases, including neoplasms. miRNA expression levels are widely reported to be associated with clinical effects of GC (41-68) (Table II). miRNA polymorphisms are also associated with GC outcomes. Stenholm et al (69) identified that polymorphisms of miR-26a, pre-miRNA of miR-27-al and pre-miRNA of miR-196-a2 were significantly associated with overall survival rates. As miRNA in formalin-fixed tissues is highly stable, and detection of circulating serum miRNA from tumors is widely studied, miRNA may be the basis of a novel system of detecting early-stage cancers (70). miRNA in serum is encapsulated in an 'exosome' that makes miRNA stable against various stresses and allows miRNA to be transferred between cells (71). Certain studies have investigated the possibility of using circulating miRNA as less invasive markers to detect and monitor GC $(70,72,73)$.

Long non-coding RNA (lncRNA). Non-coding RNA transcripts of $>200$ base pairs are designated lncRNA. Previously, lncRNA was thought to be 'junk nucleotides', but recent evidence indicates that IncRNA is as important in epigenetic modulation as miRNA (74). Aberrant expression of certain types of IncRNA has been associated with poorer prognosis 


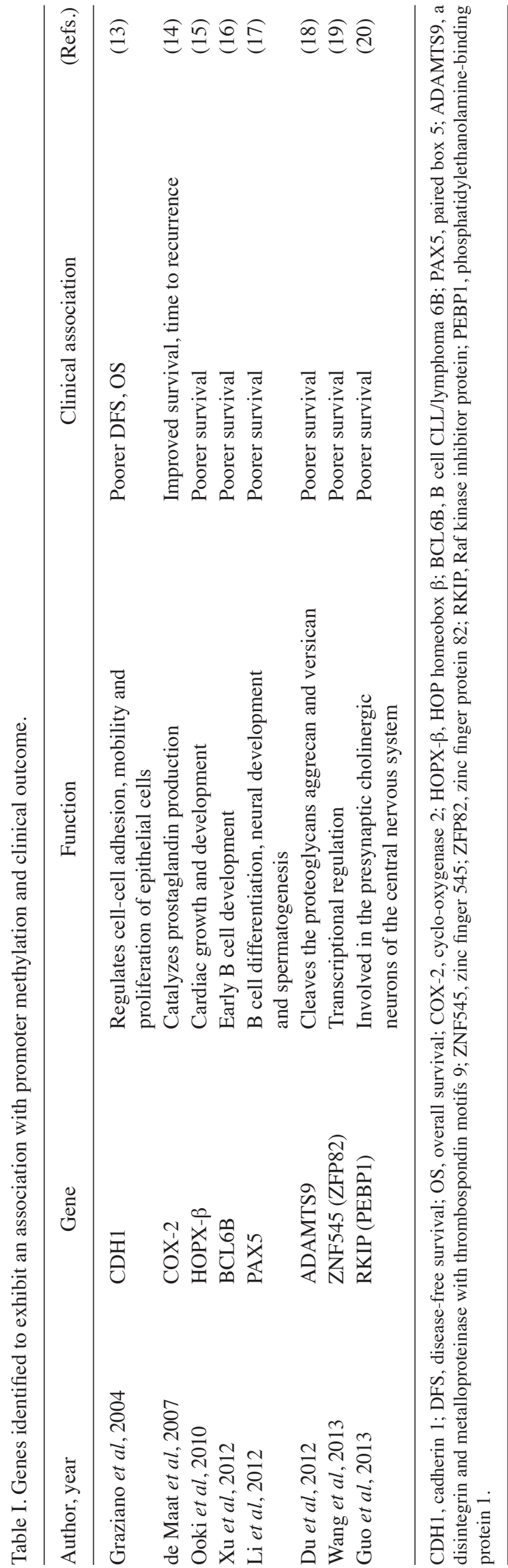

Table II. miRNAs identified to be associated with clinical outcome of gastric cancer.

\begin{tabular}{|c|c|c|}
\hline Author, year & miRNA & (Refs.) \\
\hline \multicolumn{3}{|l|}{ Highly expressed } \\
\hline Wang et al, 2013 & miR-10b & (43) \\
\hline Katada et al, 2009 & miR-20b & (53) \\
\hline Katada et al, 2009 & $\operatorname{miR}-27 a$ & (53) \\
\hline Osawa et al, 2011 & miR-34a & (65) \\
\hline Inoue et al, 2012 & miR-107 & (42) \\
\hline Liu et al, 2014 & miR-132 & (46) \\
\hline Naito et al, 2014 & miR-143 & (49) \\
\hline Katada et al, 2009 & miR-150 & (53) \\
\hline Chen et al, 2013 & miR-181a-5p & (54) \\
\hline Brenner et al, 2011 & miR-199a-3p & (56) \\
\hline Yang et al, 2013 & $\operatorname{miR}-214$ & (58) \\
\hline Liu et al, 2012 & miR-221 & (61) \\
\hline Wang et al, 2013 & miR-301a & (62) \\
\hline Yan et al, 2013 & miR-335 & (63) \\
\hline \multicolumn{3}{|l|}{ Poorly expressed } \\
\hline Liu et al, 2012 & Let-7i & (41) \\
\hline Wang et al, 2013 & miR-22 & (60) \\
\hline Hashiguchi et al, 2012 & $\operatorname{miR}-125 a-3 p$ & (44) \\
\hline Guo et al, 2013 & miR-127 & (45) \\
\hline Shin et al, 2013 & miR-135a & (47) \\
\hline Bao et al, 2011 & miR-139 & (48) \\
\hline Akiyoshi et al, 2012 & miR-144 & $(50)$ \\
\hline $\begin{array}{l}\text { Zheng et al, 2011; } \\
\text { Sakamoto et al, } 2014\end{array}$ & miR-148a & $(51,52)$ \\
\hline Tan et al, 2014 & miR-185 & (55) \\
\hline Tang et al, 2013 & miR-200b & (57) \\
\hline Tang et al, 2013 & miR-200c & (57) \\
\hline Wang et al, 2014 & miR-214 & (59) \\
\hline Zheng et al, 2012 & miR-409-3p & (64) \\
\hline Guo et al, 2013 & miR-433 & (45) \\
\hline Bandres et al, 2009 & miR-451 & (66) \\
\hline Iwaya et al, 2013 & miR-494 & (67) \\
\hline He et al, 2014 & miR-760 & $(68)$ \\
\hline
\end{tabular}

miRNA/miR, microRNA.

in breast cancer (75), hepatocellular carcinoma (76) and lung carcinoma (77); and it has recently been demonstrated to possess clinical significance in GC (78-85) (Table III). lncRNA in plasma is reportedly detectable in patients with $\mathrm{GC}$, as with miRNA (86).

\section{Conclusions}

In the present review, recent studies that have identified associations between epigenetic modulation and clinical outcomes in GC have been summarized and discussed. Epigenetic changes in the expression of specific genes critically affect their clinical significance. Further study may reveal epigenetic 
Table III. Long non-coding RNA identified to be associated with promoter methylation and clinical outcomes.

\begin{tabular}{|c|c|c|c|c|}
\hline Author, year & Gene & Status & Function & (Refs.) \\
\hline Yang et al, 2012 & H19 & Increased & Cellular proliferation, p53 inactivation & $(78)$ \\
\hline $\mathrm{Xu}$ et al, 2013 & HOTAIR & Increased & Poor OS, invasiveness & $(79)$ \\
\hline Yang et al, 2014 & GHET1 & Increased & Tumor size, tumor invasion and poor survival & $(80)$ \\
\hline Lee et al, 2014 & nc886 & Decreased & Poor survival & $(81)$ \\
\hline Xu et al, 2014 & FENDRR & Decreased & Tumor invasion, stage, lymph node metastasis, poor prognosis & $(82)$ \\
\hline Han et al, 2014 & LEIGC & Decreased & Tumor growth, cell proliferation, 5-FU sensitivity & $(83)$ \\
\hline Okugawa et al, 2014 & MALAT1 & Increased & Peritoneal dissemination & $(84)$ \\
\hline $\mathrm{Xu}$ et al, 2014 & LSINCT5 & Increased & Tumor size, depth, stage, worse DFS and DSS & $(85)$ \\
\hline
\end{tabular}

H19, H19 imprinted maternally expressed transcript; HOTAIR, HOX transcript antisense RNA; OS, overall survival; GHET1, gastric carcinoma proliferation enhancing transcript 1; nc886, vault RNA 2; FENDRR, FOXF1 adjacent non-coding developmental regulatory RNA; LEIGC, lower expression in gastric cancer; 5-FU, 5-fluorouracil; MALAT1, metastasis-associated lung adenocarcinoma transcript 1; LSINCT5, long stress-induced non-coding transcript 5; DFS, disease-free survival; DSS, disease-specific survival.

changes as the basis for targeted molecular therapy or novel biomarkers that predict GC prognosis or extension of this often fatal disease.

\section{References}

1. Bray F, Ren JS, Masuyer E and Ferlay J: Global estimates of cancer prevalence for 27 sites in the adult population in 2008. Int J Cancer 132: 1133-1145, 2013

2. Ferlay J, Soerjomataram I, Ervik M, Dikshit R, Eser S, Mathers C, Rebelo M, Parkin DM, Forman D and Bray F: GLOBOCAN 2012 v1.0, Cancer Incidence and Mortality Worldwide, IARC CancerBase No. 11. International Agency for Research on Cancer Lyon, France, 2013. http://globocan.iarc.fr. Accessed September 15, 2015.

3. Ferro A, Peleteiro B, Malvezzi M, Bosetti C, Bertuccio P, Levi F, Negri E, La Vecchia C and Lunet N: Worldwide trends in gastric cancer mortality (1980-2011), with predictions to 2015, and incidence by subtype. Eur J Cancer 50: 1330-1344, 2014.

4. Ono H, Kondo H, Gotoda T, Shirao K, Yamaguchi H, Saito D, Hosokawa K, Shimoda T and Yoshida S: Endoscopic mucosal resection for treatment of early gastric cancer. Gut 48: 225-229, 2001.

5. Gotoda T, Yamamoto H and Soetikno RM: Endoscopic submucosal dissection of early gastric cancer. J Gastroenterol 41: 929-942, 2006.

6. An international association between Helicobacter-pylori infection and gastric-cancer. The EUROGAST Study Group. Lancet 341: 1359-1362, 1993.

7. Dias-Neto M, Pintalhao M, Ferreira M and Lunet N: Salt intake and risk of gastric intestinal metaplasia: Systematic review and meta-analysis. Nutr Cancer 62: 133-147, 2010.

8. Tsugane S: Salt, salted food intake, and risk of gastric cancer: Epidemiologic evidence. Cancer Sci 96: 1-6, 2005.

9. International Human Genome Sequencing Consortium: Finishing the euchromatic sequence of the human genome. Nature 431: 931-945, 2004.

10. Jones PA and Baylin SB: The epigenomics of cancer. Cell 128: 683-692, 2007.

11. Gaudet F, Hodgson JG, Eden A, Jackson-Grusby L, Dausman J, Gray JW, Leonhardt H and Jaenisch R: Induction of tumors in mice by genomic hypomethylation. Science 300: 489-492, 2003.

12. Merlo A, Herman JG, Mao L, Lee DJ, Gabrielson E, Burger PC, Baylin SB and Sidransky D: 5' CpG island methylation is associated with transcriptional silencing of the tumor-suppressor p16/CDKN2/MTS1 in human cancers. Nat Med 1: 686-692, 1995.

13. Graziano F, Arduini F, Ruzzo A, Bearzi I, Humar B, More H, Silva R, Muretto P, Guilford P, Testa E, et al: Prognostic analysis of E-cadherin gene promoter hypermethylation in patients with surgically resected, node-positive, diffuse gastric cancer. Clin Cancer Res 10: 2784-2789, 2004
14. de Maat MF, van de Velde CJ, Umetani N, de Heer P, Putter H, van Hoesel AQ, Meijer GA, van Grieken NC, Kuppen PJ, Bilchik AJ, et al: Epigenetic silencing of cyclooxygenase-2 affects clinical outcome in gastric cancer. J Clin Oncol 25: 4887-4894, 2007.

15. Ooki A, Yamashita K, Kikuchi S, Sakuramoto S, Katada N Kokubo K, Kobayashi H, Kim MS, Sidransky D and Watanabe M: Potential utility of HOP homeobox gene promoter methylation as a marker of tumor aggressiveness in gastric cancer. Oncogene 29: 3263-3275, 2010.

16. Xu L, Li X, Chu ES, Zhao G, Go MY, Tao Q, Jin H, Zeng Z, Sung JJ and $\mathrm{Yu}$ J: Epigenetic inactivation of BCL6B, a novel functional tumour suppressor for gastric cancer, is associated with poor survival. Gut 61: 977-985, 2012.

17. Li X, Cheung KF, Ma X, Tian L, Zhao J, Go MY, Shen B, Cheng AS, Ying J, Tao Q, et al: Epigenetic inactivation of paired box gene 5, a novel tumor suppressor gene, through direct upregulation of p53 is associated with prognosis in gastric cancer patients. Oncogene 31: 3419-3430, 2012.

18. Du W, Wang S, Zhou Q, Li X, Chu J, Chang Z, Tao Q, Ng EK, Fang J, Sung JJ and Yu J: ADAMTS9 is a functional tumor suppressor through inhibiting AKT/mTOR pathway and associated with poor survival in gastric cancer. Oncogene 32: 3319-3328, 2013.

19. Wang S, Cheng Y, Du W, Lu L, Zhou L, Wang H, Kang W, Li X, Tao Q, Sung JJ and Yu J: Zinc-finger protein 545 is a novel tumour suppressor that acts by inhibiting ribosomal RNA transcription in gastric cancer. Gut 62: 833-841, 2013.

20. Guo W, Dong Z, Guo Y, Lin X, Chen Z, Kuang G and Yang Z: Aberrant methylation and loss expression of RKIP is associated with tumor progression and poor prognosis in gastric cardia adenocarcinoma. Clin Exp Metastasis 30: 265-275, 2013.

21. Cravo M, Pinto R, Fidalgo P, Chaves P, Glória L, Nobre-Leitão C and Costa Mira F: Global DNA hypomethylation occurs in the early stages of intestinal type gastric carcinoma. Gut 39: 434-438, 1996.

22. Balassiano K, Lima S, Jenab M, Overvad K, Tjonneland A, Boutron-Ruault MC, Clavel-Chapelon F, Canzian F, Kaaks R, Boeing $\mathrm{H}$, et al: Aberrant DNA methylation of cancer-associated genes in gastric cancer in the European Prospective Investigation into Cancer and Nutrition (EPIC-EURGAST). Cancer Lett 311: 85-95, 2011.

23. Bae JM, Shin SH, Kwon HJ, Park SY, Kook MC, Kim YW, Cho NY, Kim N, Kim TY, Kim D and Kang GH: ALU and LINE-1 hypomethylations in multistep gastric carcinogenesis and their prognostic implications. Int J Cancer 131: 1323-1331, 2012.

24. Shigaki H, Baba Y, Watanabe M, Murata A, Iwagami S, Miyake K, Ishimoto T, Iwatsuki $\mathrm{M}$ and Baba H: LINE-1 hypomethylation in gastric cancer, detected by bisulfite pyrosequencing, is associated with poor prognosis. Gastric Cancer 16: 480-487, 2013.

25. Maekita T, Nakazawa K, Mihara M, Nakajima T, Yanaoka K, Iguchi M, Arii K, Kaneda A, Tsukamoto T, Tatematsu M, et al: High levels of aberrant DNA methylation in Helicobacter pylori-infected gastric mucosae and its possible association with gastric cancer risk. Clin Cancer Res 12: 989-995, 2006. 
26. Chan AO, Lam SK, Wong BC, Wong WM, Yuen MF, Yeung YH, Hui WM, Rashid A and Kwong YL: Promoter methylation of E-cadherin gene in gastric mucosa associated with Helicobacter pylori infection and in gastric cancer. Gut 52: 502-506, 2003.

27. Kang GH, Lee S, Kim WH, Lee HW, Kim JC, Rhyu MG and Ro JY: Epstein-barr virus-positive gastric carcinoma demonstrates frequent aberrant methylation of multiple genes and constitutes $\mathrm{CpG}$ island methylator phenotype-positive gastric carcinoma. Am J Pathol 160: 787-794, 2002.

28. Xu D, Qu L, Hu J, Li G, Lv P, Ma D, Guo M and Chen Y: Transmembrane protein 106A is silenced by promoter region hypermethylation and suppresses gastric cancer growth by inducing apoptosis. J Cell Mol Med 18: 1655-1666, 2014.

29. Kim HG, Lee S, Kim DY, Ryu SY, Joo JK, Kim JC, Lee KH and Lee JH: Aberrant methylation of DNA mismatch repair genes in elderly patients with sporadic gastric carcinoma: A comparison with younger patients. J Surg Oncol 101: 28-35, 2010.

30. Luco RF, Pan Q, Tominaga K, Blencowe BJ, Pereira-Smith OM and Misteli T: Regulation of alternative splicing by histone modifications. Science 327: 996-1000, 2010.

31. Nishiyama A, Yamaguchi L, Sharif J, Johmura Y, Kawamura T, Nakanishi K, Shimamura S, Arita K, Kodama T, Ishikawa F, et al: Uhrf1-dependent H3K23 ubiquitylation couples maintenance DNA methylation and replication. Nature 502: 249-253, 2013.

32. Barski A, Cuddapah S, Cui K, Roh TY, Schones DE, Wang Z, Wei G, Chepelev I and Zhao K: High-resolution profiling of histone methylations in the human genome. Cell 129: 823-837, 2007.

33. Archer SY and Hodin RA: Histone acetylation and cancer. Curr Opin Genet Dev 9: 171-174, 1999.

34. Ota T, Suto S, Katayama H, Han ZB, Suzuki F, Maeda M, Tanino M, Terada $Y$ and Tatsuka M: Increased mitotic phosphorylation of histone $\mathrm{H} 3$ attributable to AIM-1/Aurora-B overexpression contributes to chromosome number instability. Cancer Res 62: 5168-5177, 2002

35. Ke Q, Davidson T, Chen H, Kluz T and Costa M: Alterations of histone modifications and transgene silencing by nickel chloride. Carcinogenesis 27: 1481-1488, 2006.

36. Dawson MA and Kouzarides T: Cancer epigenetics: From mechanism to therapy. Cell 150: 12-27, 2012

37. Cai L, Ma X, Huang Y, Zou Y and Chen X: Aberrant histone methylation and the effect of Suv39H1 siRNA on gastric carcinoma. Oncol Rep 31: 2593-2600, 2014.

38. Yekta S, Shih IH and Bartel DP: MicroRNA-directed cleavage of HOXB8 mRNA. Science 304: 594-596, 2004.

39. Hutvagner G and Zamore PD: A microRNA in a multiple-turnover RNAi enzyme complex. Science 297: 2056-2060, 2002.

40. Lewis BP, Burge CB and Bartel DP: Conserved seed pairing, often flanked by adenosines, indicates that thousands of human genes are microRNA targets. Cell 120: 15-20, 2005.

41. Liu K, Qian T, Tang L, Wang J, Yang H and Ren J: Decreased expression of microRNA let-7i and its association with chemotherapeutic response in human gastric cancer. World J Surg Oncol 10: 225, 2012

42. Inoue T, Iinuma H, Ogawa E, Inaba T and Fukushima R: Clinicopathological and prognostic significance of microRNA-107 and its relationship to DICER1 mRNA expression in gastric cancer. Oncol Rep 27: 1759-1764, 2012.

43. Wang YY, Ye ZY, Zhao ZS, Li L, Wang YX, Tao HQ, Wang HJ and He XJ: Clinicopathologic significance of miR-10b expression in gastric carcinoma. Hum Pathol 44: 1278-1285, 2013.

44. Hashiguchi Y, Nishida N, Mimori K, Sudo T, Tanaka F, Shibata K, Ishii H, Mochizuki H, Hase K, Doki Y and Mori M: Down-regulation of miR-125a-3p in human gastric cancer and its clinicopathological significance. Int J Oncol 40: 1477-1482, 2012.

45. Guo LH, Li H, Wang F, Yu J and He JS: The tumor suppressor roles of miR-433 and miR-127 in gastric cancer. Int J Mol Sci 14: 14171-14184, 2013

46. Liu X, Yu H, Cai $\mathrm{H}$ and Wang Y: The expression and clinical significance of miR-132 in gastric cancer patients. Diagn Pathol 9: 57, 2014

47. Shin JY, Kim YI, Cho SJ, Lee MK, Kook MC, Lee JH, Lee SS, Ashktorab H, Smoot DT, Ryu KW, et al: MicroRNA 135a suppresses lymph node metastasis through down-regulation of ROCK1 in early gastric cancer. PLoS One 9: e85205, 2014.

48. Bao W, Fu HJ, Xie QS, Wang L, Zhang R, Guo ZY, Zhao J, Meng YL, Ren XL, Wang T, et al: HER2 interacts with CD44 to up-regulate CXCR4 via epigenetic silencing of microRNA-139 in gastric cancer cells. Gastroenterology 141: 2076-2087.e6, 2011 .
49. Naito Y, Sakamoto N, Oue N, Yashiro M, Sentani K, Yanagihara K, Hirakawa K and Yasui W: MicroRNA-143 regulates collagen type III expression in stromal fibroblasts of scirrhous type gastric cancer. Cancer Sci 105: 228-235, 2014

50. Akiyoshi S, Fukagawa T, Ueo H, Ishibashi M, Takahashi Y, Fabbri M, Sasako M, Maehara Y, Mimori K and Mori M: Clinical significance of miR-144-ZFX axis in disseminated tumour cells in bone marrow in gastric cancer cases. Br J Cancer 107: 1345-1353, 2012

51. Zheng B, Liang L, Wang C, Huang S, Cao X, Zha R, Liu L, Jia D, Tian Q, Wu J, et al: MicroRNA-148a suppresses tumor cell invasion and metastasis by downregulating ROCK1 in gastric cancer. Clin Cancer Res 17: 7574-7583, 2011.

52. Sakamoto N, Naito Y, Oue N, Sentani K, Uraoka N, Zarni Oo H, Yanagihara K, Aoyagi K, Sasaki H and Yasui W: MicroRNA-148a is downregulated in gastric cancer, targets MMP7, and indicates tumor invasiveness and poor prognosis. Cancer Sci 105: 236-243, 2014.

53. Katada T, Ishiguro H, Kuwabara Y, Kimura M, Mitui A, Mori Y, Ogawa R, Harata K and Fujii Y: microRNA expression profile in undifferentiated gastric cancer. Int J Oncol 34: 537-542, 2009

54. Chen G, Shen ZL, Wang L, Lv CY, Huang XE and Zhou RP: Hsa-miR-181a-5p expression and effects on cell proliferation in gastric cancer. Asian Pac J Cancer Prev 14: 3871-3875, 2013.

55. Tan Z, Jiang H, Wu Y, Xie L, Dai W, Tang H and Tang S: miR-185 is an independent prognosis factor and suppresses tumor metastasis in gastric cancer. Mol Cell Biochem 386: 223-231, 2014

56. Brenner B, Hoshen MB, Purim O, David MB, Ashkenazi K, Marshak G, Kundel Y, Brenner R, Morgenstern S, Halpern M, et al: MicroRNAs as a potential prognostic factor in gastric cancer. World J Gastroenterol 17: 3976-3985, 2011.

57. Tang H, Deng M, Tang Y, Xie X, Guo J, Kong Y, Ye F, Su Q and Xie X: miR-200b and miR-200c as prognostic factors and mediators of gastric cancer cell progression. Clin Cancer Res 19: 5602-5612, 2013

58. Yang TS, Yang XH, Wang XD, Wang YL, Zhou B and Song ZS: MiR-214 regulate gastric cancer cell proliferation, migration and invasion by targeting PTEN. Cancer Cell Int 13: 68, 2013.

59. Wang M, Zhao C, Shi H, Zhang B, Zhang L, Zhang X, Wang S Wu X, Yang T, Huang F, et al: Deregulated microRNAs in gastric cancer tissue-derived mesenchymal stem cells: Novel biomarkers and a mechanism for gastric cancer. Br J Cancer 110: 1199-1210, 2014.

60. Wang W, Li F, Zhang Y, Tu Y, Yang Q and Gao X: Reduced expression of miR-22 in gastric cancer is related to clinicopathologic characteristics or patient prognosis. Diagn Pathol 8: 102, 2013.

61. Liu K, Li G, Fan C, Diao Y, Wu B and Li J: Increased expression of MicroRNA-221 in gastric cancer and its clinical significance. J Int Med Res 40: 467-474, 2012

62. Wang M, Li C, Yu B, Su L, Li J, Ju J, Yu Y, Gu Q, Zhu Z and Liu B: Overexpressed miR-301a promotes cell proliferation and invasion by targeting RUNX3 in gastric cancer. J Gastroenterol 48: 1023-1033, 2013

63. Yan Z, Xiong Y, Xu W, Gao J, Cheng Y, Wang Z, Chen F and Zheng G: Identification hsa-miR-335 as a prognostic signature in gastric cancer. PLoS One 7: e40037, 2012.

64. Zheng B, Liang L, Huang S, Zha R, Liu L, Jia D, Tian Q, Wang Q, Wang C, Long Z, et al: MicroRNA-409 suppresses tumour cell invasion and metastasis by directly targeting radixin in gastric cancers. Oncogene 31: 4509-4516, 2012.

65. Osawa S, Shimada Y, Sekine S, Okumura T, Nagata T, Fukuoka J and Tsukada K: MicroRNA profiling of gastric cancer patients from formalin-fixed paraffin-embedded samples. Oncol Lett 2: 613-619, 2011.

66. Bandres E, Bitarte N, Arias F, Agorreta J, Fortes P, Agirre X, Zarate R, Diaz-Gonzalez JA, Ramirez N, Sola JJ, et al: microRNA-451 regulates macrophage migration inhibitory factor production and proliferation of gastrointestinal cancer cells. Clin Cancer Res 15: 2281-2290, 2009.

67. Iwaya T, Fukagawa T, Suzuki Y, Takahashi Y, Sawada G, Ishibashi M, Kurashige J, Sudo T, Tanaka F, Shibata K, et al: Contrasting expression patterns of histone mRNA and microRNA 760 in patients with gastric cancer. Clin Cancer Res 19: 6438-6449, 2013.

68. He W, Li Y, Chen X, Lu L, Tang B, Wang Z, Pan Y, Cai S, $\mathrm{He} \mathrm{Y}$ and $\mathrm{Ke} \mathrm{Z}$ : miR-494 acts as an anti-oncogene in gastric carcinoma by targeting c-myc. J Gastroenterol Hepatol 29: 1427-1434, 2014 
69. Stenholm L, Stoehlmacher-Williams J, Al-Batran SE, Heussen N, Akin S, Pauligk C, Lehmann S, Senff T, Hofheinz RD, Ehninger G, et al: Prognostic role of microRNA polymorphisms in advanced gastric cancer: A translational study of the Arbeitsgemeinschaft Internistische Onkologie (AIO). Ann Oncol 24: 2581-2588, 2013

70. Tsujiura M, Ichikawa D, Komatsu S, Shiozaki A, Takeshita H, Kosuga T, Konishi H, Morimura R, Deguchi K, Fujiwara H, et al: Circulating microRNAs in plasma of patients with gastric cancers. Br J Cancer 102: 1174-1179, 2010.

71. Valadi H, Ekström K, Bossios A, Sjöstrand M, Lee JJ and Lötvall JO: Exosome-mediated transfer of mRNAs and microRNAs is a novel mechanism of genetic exchange between cells. Nat Cell Biol 9: 654-659, 2007.

72. Liu R, Zhang C, Hu Z, Li G, Wang C, Yang C, Huang D, Chen X, Zhang $\mathrm{H}$, Zhuang R, et al: A five-microRNA signature identified from genome-wide serum microRNA expression profiling serves as a fingerprint for gastric cancer diagnosis. Eur J Cancer 47: 784-791, 2011

73. Liu H, Zhu L, Liu B, Yang L, Meng X, Zhang W, Ma Y and Xiao H: Genome-wide microRNA profiles identify miR-378 as a serum biomarker for early detection of gastric cancer. Cancer Lett 316: 196-203, 2012.

74. Ponting CP, Oliver PL and Reik W: Evolution and functions of long noncoding RNAs. Cell 136: 629-641, 2009.

75. Gupta RA, Shah N, Wang KC, Kim J, Horlings HM, Wong DJ, Tsai MC, Hung T, Argani P, Rinn JL, et al: Long non-coding RNA HOTAIR reprograms chromatin state to promote cancer metastasis. Nature 464: 1071-1076, 2010.

76. Yang Z, Zhou L, Wu LM, Lai MC, Xie HY, Zhang F and Zheng SS: Overexpression of long non-coding RNA HOTAIR predicts tumor recurrence in hepatocellular carcinoma patients following liver transplantation. Ann Surg Oncol 18: 1243-1250, 2011.

77. Gutschner T, Hammerle M, Eissmann M, Hsu J, Kim Y, Hung G, Revenko A, Arun G, Stentrup M, Gross M, et al: The noncoding RNA MALAT1 is a critical regulator of the metastasis phenotype of lung cancer cells. Cancer Res 73: 1180-1189, 2013.
78. Yang F, Bi J, Xue X, Zheng L, Zhi K, Hua J and Fang G: Up-regulated long non-coding RNA H19 contributes to proliferation of gastric cancer cells. FEBS J 279: 3159-3165, 2012.

79. Xu ZY, Yu QM, Du YA, Yang LT, Dong RZ, Huang L, Yu PF and Cheng XD: Knockdown of long non-coding RNA HOTAIR suppresses tumor invasion and reverses epithelial-mesenchymal transition in gastric cancer. Int J Biol Sci 9: 587-597, 2013.

80. Yang F, Xue X, Zheng L, Bi J, Zhou Y, Zhi K, Gu Y and Fang G: Long non-coding RNA GHET1 promotes gastric carcinoma cell proliferation by increasing c-Myc mRNA stability. FEBS J 281: 802-813, 2014

81. Lee KS, Park JL, Lee K, Richardson LE, Johnson BH, Lee HS, Lee JS, Kim SB, Kwon OH, Song KS, et al: nc886, a non-coding RNA of anti-proliferative role, is suppressed by CpG DNA methylation in human gastric cancer. Oncotarget 5: 3944-3955, 2014.

82. Xu TP, Huang MD, Xia R, Liu XX, Sun M, Yin L, Chen WM, Han L, Zhang EB, Kong R, et al: Decreased expression of the long non-coding RNA FENDRR is associated with poor prognosis in gastric cancer and FENDRR regulates gastric cancer cell metastasis by affecting fibronectin 1 expression. J Hematol Oncol 7: 63, 2014.

83. Han Y, Ye J, Wu D, Wu P, Chen Z, Chen J, Gao S and Huang J: LEIGC long non-coding RNA acts as a tumor suppressor in gastric carcinoma by inhibiting the epithelial-to-mesenchymal transition. BMC Cancer 14: 932, 2014

84. Okugawa Y, Toiyama Y, Hur K, Toden S, Saigusa S, Tanaka K, Inoue Y, Mohri Y, Kusunoki M, Boland CR and Goel A: Metastasis-associated long non-coding RNA drives gastric cancer development and promotes peritoneal metastasis. Carcinogenesis 35: 2731-2739, 2014.

85. Xu MD, Qi P, Weng WW, Shen XH, Ni SJ, Dong L, Huang D, Tan C, Sheng WQ, Zhou XY and Du X: Long non-coding RNA LSINCT5 predicts negative prognosis and exhibits oncogenic activity in gastric cancer. Medicine (Baltimore) 93: e303, 2014.

86. Arita T, Ichikawa D, Konishi H, Komatsu S, Shiozaki A, Shoda K, Kawaguchi T, Hirajima S, Nagata H, Kubota T, et al: Circulating long non-coding RNAs in plasma of patients with gastric cancer. Anticancer Res 33: 3185-3193, 2013. 